\title{
Epidemiology of Foliar Blights (Spot Blotch and Tan Spot) of Wheat in the Plains Bordering the Himalayas
}

\author{
E. Duveiller, Y. R. Kandel, R. C. Sharma, and S. M. Shrestha
}

First author: CIMMYT, South Asia Regional Office, P.O. Box 5186, Kathmandu, Nepal; and second, third, and fourth authors: Institute of Agriculture and Animal Science, Rampur, Chitwan, Nepal. Accepted for publication 18 October 2004.

\begin{abstract}
Duveiller, E., Kandel, Y. R., Sharma, R. C., and Shrestha, S. M. 2005. Epidemiology of foliar blights (spot blotch and tan spot) of wheat in the plains bordering the Himalayas. Phytopathology 95:248-256.

Helminthosporium leaf blight (HLB), a complex of spot blotch caused by Cochliobolus sativus and of tan spot caused by Pyrenophora triticirepentis, is a major wheat disease in South Asia. This 2-year study elucidated HLB development and its impact on yield. Symptoms caused by $C$. sativus and $P$. tritici-repentis were first observed at the seedling and tillering stages, respectively. The number of airborne conidia and leaves infected by the two pathogens remained low for several weeks under lower temperatures, followed by a sharp rise as temperatures increased. The number of airborne conidia of $C$. sativus and incidence of infection by $C$. sativus were higher compared with $P$. tritici-repentis. The disease
\end{abstract}

ABSTRACT complex caused an average 30\% reduction in yield, with greater losses under delayed seeding. Delayed seeding increased disease severity even in resistant genotypes and caused higher yield losses. 'Milan/Shanghai-7' was the most resistant among six genotypes evaluated. Despite higher disease severity, 'BL 1473' showed relatively lower yield losses, indicating its tolerance to foliar blight. The findings of this study bear implications for integrated foliar blight management in the warmer areas of South Asia by combining optimum seeding date, seed treatment and foliar spray of fungicides, and resistant wheat genotypes.

Additional keywords: Bipolaris sorokiniana, Drechslera tritici-repentis, Indo-Gangetic Plains, integrated crop management, host resistance, ricewheat system, Triticum aestivum.
Successful production of bread wheat (Triticum aestivum L.) in the warmer regions of South Asia is constrained by several biotic and abiotic stresses $(11-13,19,28,38)$. In the vast Indo-Gangetic Plains, heat stress during grain filling caused by late planting is a major limitation to higher wheat yields (19). The most important disease is foliar blight, also referred to as Helminthosporium leaf blight (HLB). It occurs as a complex of spot blotch, caused by Cochliobolus sativus (Ito \& Kuribayashi) Drechs. ex Dastur (anamorph Bipolaris sorokiniana (Sacc.) Shoemaker) and tan spot, caused by Pyrenophora tritici-repentis (Died.) Drechs. (anamorph Drechslera tritici-repentis (Died.) Shoemaker) (14,22,32,44). Globally, an estimated 25 million ha of wheat land is affected by spot blotch (44). Of these, $\approx 10$ million ha are in the Indian Subcontinent, including 9 million ha in India alone, mostly in the rice-wheat cropping system (24). For the past several years, HLB severity on wheat has been high in the entire eastern plain zone of the Indian Subcontinent, where millions of resource-poor people rely on wheat (13). In South Asia, yield losses due to HLB have been reported to reach up to 20 to $30 \%$ in farmers' fields and experiment stations $(9,14,32,38)$. In years when rain occurs late in the crop cycle, especially during grain filling, complete crop loss has been observed (34).

In South Asia, Saari (32) pointed out that the most widely applied rice-wheat cropping system provided a favorable environment for the survival and multiplication of foliar blight pathogens because rice serves as a host species for the spot blotch and tan spot fungi and rice stubble also may play a role as a substrate for the fungi after rice harvest (23). Crop growth stage and weather, in particular high temperatures and humidity favoring long dura-

Corresponding author: E. Duveiller; E-mail address: E.Duveiller@cgiar.org

DOI: 10.1094/PHYTO-95-0248

(C) 2005 The American Phytopathological Society tion of leaf wetness, are considered to be associated with foliar blight development $(5,25,29,35)$. Indeed, preliminary epidemiological observations suggest that the combined effects of high temperature, high relative humidity, and long periods $(>12 \mathrm{~h})$ of leaf wetness caused by rainfall or dew are conducive to foliar blight development in the Indo-Gangetic Plains where wheat is grown from November to April (13). In Brazil, Reis (29) suggested that, for foliar blight outbreaks to occur, wheat leaves must remain wet for $>18 \mathrm{~h}$ at a mean temperature of $18^{\circ} \mathrm{C}$ or higher. In Asia, Nema and Joshi (25) and Singh et al. (41) reported that infection by $C$. sativus was more rapid and more severe at $28^{\circ} \mathrm{C}$ than at lower temperatures.

In Nepal, Dubin and Bimb (10) reported a higher level of conidial dispersal of $P$. tritici-repentis in February, accompanied by higher foliar blight incidence, and indicated that $C$. sativus became predominant only later in the season as temperature increased and wheat maturity progressed.

Factors such as minimum tillage or surface seeding, irrigation, late planting, or low soil fertility may be responsible for higher foliar blight severity in the wheat-based cropping systems of the Indo-Gangetic Plains (38). Seeding dates could be adjusted slightly to reduce spot blotch incidence on wheat during the postflowering period (18). By adjusting the sowing date, it was possible to keep high air temperatures from coinciding with critical physiological growth stages (e.g., anthesis). Also, early seeding is recommended for reducing losses due to HLB in areas where rainfall increases at the end of the wheat season, as it does in Assam, the southern parts of eastern India and Bangladesh, and parts of South America. In Uttar Pradesh (eastern India), Singh et al. (41) reported that late-sown (30 December) wheat fields suffered more from foliar blight than plots sown on the optimal date (30 November). Although different abiotic factors interact in HLB development (38), these observations show that more quantitative information is needed to understand the role of weather and seed- 
ing date in disease development. Such information would be essential to making crop management recommendations that would effectively control HLB epidemics in the rice-wheat cropping system of South Asia.

Previous studies have documented the epidemiology of $P$. triticirepentis under a cool, temperate climate $(20,26,45)$. However, no detailed epidemiological study on the rice-wheat system is available for either pathogen. It is equally important to understand changes in disease severity associated with differences in seeding time that affect agronomic traits and critical growth stages of wheat sown on the optimum and late seeding dates. The interaction between crop growth stage and the level of airborne inoculum of foliar blight pathogens and, as a result, disease severity and poor agronomic performance, are not well understood in South Asia. The present study was conducted to (i) observe symptom initiation and foliar blight progress in contrasting wheat genotypes, (ii) monitor airborne conidia of $C$. sativus and P. triticirepentis throughout the wheat season, and (iii) compare disease epidemics and levels of foliar blight damage on grain yield and thousand-kernel weight of wheat grown under optimum, intermediate, and late seeding conditions. This information is critical for an efficient integrated crop management strategy to control leaf blights caused by $C$. sativus and $P$. tritici-repentis in warmer wheat-growing areas of the world.

\section{MATERIALS AND METHODS}

Test site. The trial was conducted in Nepal at the experimental field of the Institute of Agriculture and Animal Science (IAAS), Rampur (Chitwan), during the 2001-02 (2002) and 2002-03 (2003) wheat-growing seasons. The Rampur site $\left(27^{\circ} 40^{\prime} \mathrm{N}\right.$, $84^{\circ} 19^{\prime} \mathrm{E}$ ) is located $228 \mathrm{~m}$ above sea level, $\approx 20 \mathrm{~km}$ from the Himalayan Mountains. This foothills location belongs to the eastern Indo-Gangetic Plains that span Bangladesh, India, and Nepal. The location is characterized by a humid subtropical climate. The soil type at the experimental site is a medium-textured loam.

Wheat genotypes and trial management. Six wheat genotypes, Sonalika (=RR 21), BL 1473, Nepal 297, NL 750, NL 781, and Milan/Shanghai-7, differing in genetic background, yield potential, maturity, and level of HLB resistance, were used in the study. Sonalika, BL 1473, and Nepal 297 are early-maturing commercial wheat cultivars in Nepal that are susceptible to HLB $(13,43)$. NL 750, NL 781, and Milan/Shanghai-7 are late-maturing, well-adapted, advanced breeding lines with high levels of resistance to $\operatorname{HLB}(18,43)$.

The field experiment was laid out in a strip-split-plot system in a randomized complete block with four replicates. Two factors were assigned to the main strips: seeding date and fungicide spray. The two strips for fungicide spray consisted of a strip fully protected by multiple spraying and a nonprotected strip. Each intersection plot formed by the fungicide spray and seeding date strips was further arranged in a group-balanced randomized complete block. Intersection plots were split in two to adjust for earlyand late-maturing groups of genotypes. The three genotypes in each maturity group were assigned randomly to three experimental plots within a group block.

In both years, the three seeding dates used were 26 November and 11 and 26 December. The optimum sowing time in the region ranges from 20 to 30 November. The fungicide-protected strip was sprayed every 10 days with Opus (BASF) (epoxiconazole at 125 a.i. g/liter) at a rate of 1 liter ha $^{-1}$ of commercial product in 250 liters of water starting from 50 days after seeding until crop physiological maturity. An additional adjacent nontreated strip identical to the fungicide nonprotected strip was seeded in each replicate so that leaf samples for pathogen observation in the laboratory could be collected weekly without affecting disease development and yield components in experimental plots.
Each individual experimental plot was 2 by $1 \mathrm{~m}$ in area and consisted of four rows with $0.25-\mathrm{m}$ spacing sown using the standard seed rate of $120 \mathrm{~kg} \mathrm{ha}^{-1}$. Untreated seed were used in both years for seeding the trial. Fertilizers were applied $\left(\mathrm{N}, \mathrm{P}_{2} \mathrm{O}_{5}\right.$ and $\mathrm{K}_{2} \mathrm{O}$ at 120,60 , and $40 \mathrm{~kg} \mathrm{ha}^{-1}$, respectively) as a basal dose, except for $\mathrm{N}$ at $20 \mathrm{~kg} \mathrm{ha}^{-1}$, which was top-dressed at tillering. Three irrigations were given as required for a successful wheat crop in Nepal's lowland environments. Plots were kept free from weeds by hand weeding. Daily rainfall, average air temperature, and relative humidity during the wheat-growing season were recorded from emergence to harvest in the two test years with a Watchdog Model 425 (Spectrum Technologies, Inc., Plainfield, IL) data logger installed in the research plot.

Airborne conidia, leaf sample collection, and pathogen incidence. To understand the association between inoculum and epidemic development, the number of conidia of both pathogens in the air above the field was monitored for 17 weeks from emergence in both years using a Rotorod Model 20 sampler (Multidata, St. Louis Park, MN) installed in the research field with sampling rods positioned slightly above the crop canopy $(1.2 \mathrm{~m}$ above ground level). The system, controlled by a timer, rotated for $1 \mathrm{~min}$ at 10 -min intervals at 2,400 $\mathrm{min}^{-1}$ (1). The spore-collecting rods, made sticky by applying a thin layer of silicon grease, were replaced weekly with new, clean rods. The total number of conidia trapped on the rods' sampling surface was counted every week under the light microscope at $\times 100$ magnification.

To study the incidence of both pathogens, leaf samples were collected from each unsprayed sampling strip at 7-day intervals starting 1 week after emergence until Zadoks' growth stage DC92 $(43,47)$ and incubated and observed in the laboratory. Twenty leaves from different plants were sampled per plot (five leaves from each of the four rows in a plot). Leaf sampling was done in a manner to cover the entire area of each plot. Samples consisted of either infected single leaves or the lowermost uninjured green leaf of a plant when symptoms were not visible. Older tissues express more symptoms for both $C$. sativus (29) and P. tritici-repentis (27); therefore, lowermost leaves were sampled to confirm the presence of pathogens when symptoms were not visible. Sampling this way allowed detection of the maximum incidence of infection in the field. It was not possible to sample from the same height in the canopy because the six wheat genotypes had reached different heights at a given time, particularly during early growth stages. After surface sterilization in $1 \%$ chlorine and rinsing in sterile distilled water, leaf blades were cut into 1-cm-long pieces and placed in petri dishes containing sterile, moist blotting paper. Dishes were incubated at room temperature on a shelf under continuous light for $48 \mathrm{~h}$, followed by a dark period of $16 \mathrm{~h}$. This alternating light and dark regime allowed profuse conidia formation of both pathogens (40). After incubation, the leaf pieces were observed directly under a stereomicroscope. The occurrence of both pathogen species was determined by examining conidia production of each pathogen separately. The number of leaves infected by $C$. sativus and $P$. tritici-repentis was recorded and pathogen incidence was determined.

Disease assessment. After anthesis, disease severity in fungicide-nonprotected plots was evaluated using the double-digit scale (00 to 99) developed as a modification of Saari and Prescott's scale for assessing severity of foliar diseases of wheat $(16,33)$. The first digit $\left(D_{1}\right)$ indicates disease progress in canopy height from the ground level and the second digit $\left(D_{2}\right)$ refers to severity measured based on diseased leaf area. Both $D_{1}$ and $D_{2}$ are scored on a scale of 1 to 9 . Four individual disease scores per plot were recorded at 3- to 7-day intervals over a 3- to 4-week period between anthesis and dough stage depending on seeding date. Intervals were longer for timely seeded wheat and shorter for late-sown wheat. For each evaluation, percent disease severity was estimated based on the formula $\%$ severity $=\left(D_{1} / 9\right) \times$ $\left(\mathrm{D}_{2} / 9\right) \times 100$. 
The area under the disease progress curve (AUDPC) was calculated using the percent severity estimations corresponding to the four ratings, as outlined by Shaner and Finney (37). The AUDPC was standardized by dividing by the total number of days in the evaluation period (AUDPC/day) to directly compare among epidemics of different lengths for the three seeding dates (30). The AUDPC also was standardized by dividing by the total number of degree-days (AUDPC/DD) for making comparisons among epidemics related to different temperature effects for the three seeding dates. The value of degree-days per assessment period was calculated as the sum of daily mean temperatures $\left({ }^{\circ} \mathrm{C}\right)$ during that period.

Agronomic traits. At maturity, all plants in plot were hand harvested, threshed, and grain weight was recorded. One thousand kernels were counted randomly from each plot's seed package and weighed to determine thousand-kernel weight (TKW).

Data analysis. The number of leaf samples over four replications $(n=80)$ infected with $C$. sativus and $P$. tritici-repentis in successive weeks of observation was used to evaluate incidence by both pathogens. Similarly, the number of conidia of both pathogens counted on the spore sampler over time was used to determine when they were detected in the air and in what number.

Statistical analysis included analysis of variance for individual years using Genstat software (Genstat for Windows, 6th edition;
Lawes Agricultural Trust, Rothamsted Experimental Station, Harpenden, UK). Varietal resistance to HLB was characterized on the basis of frequency of leaves infected by the pathogens, AUDPC, and reductions in grain yield and TKW. The values for AUDPC/day and AUDPC/DD under the three seeding dates were compared to determine whether the disease caused more severe destruction of plant leaves and, hence, greater grain yield reduction, under timely or late seeding. Mean grain yield and TKW under fungicide-protected and nonprotected conditions were compared to determine losses caused by the disease. Disease variables (AUDPC, AUDPC/day, and AUDPC/DD) were plotted against seeding date to examine relationships between the two. Reductions in grain yield for three seeding dates were compared to determine disease contribution to yield losses in timely or late-seeded wheat. All mean separations were accomplished using a least significance differences test at the 5\% probability level.

\section{RESULTS}

Weather conditions. Mean daily temperature and relative humidity showed similar trends in both years (Fig. 1A), although average temperatures were lower in 2003 than in 2002 during most of the wheat-growing season. In particular, the month of

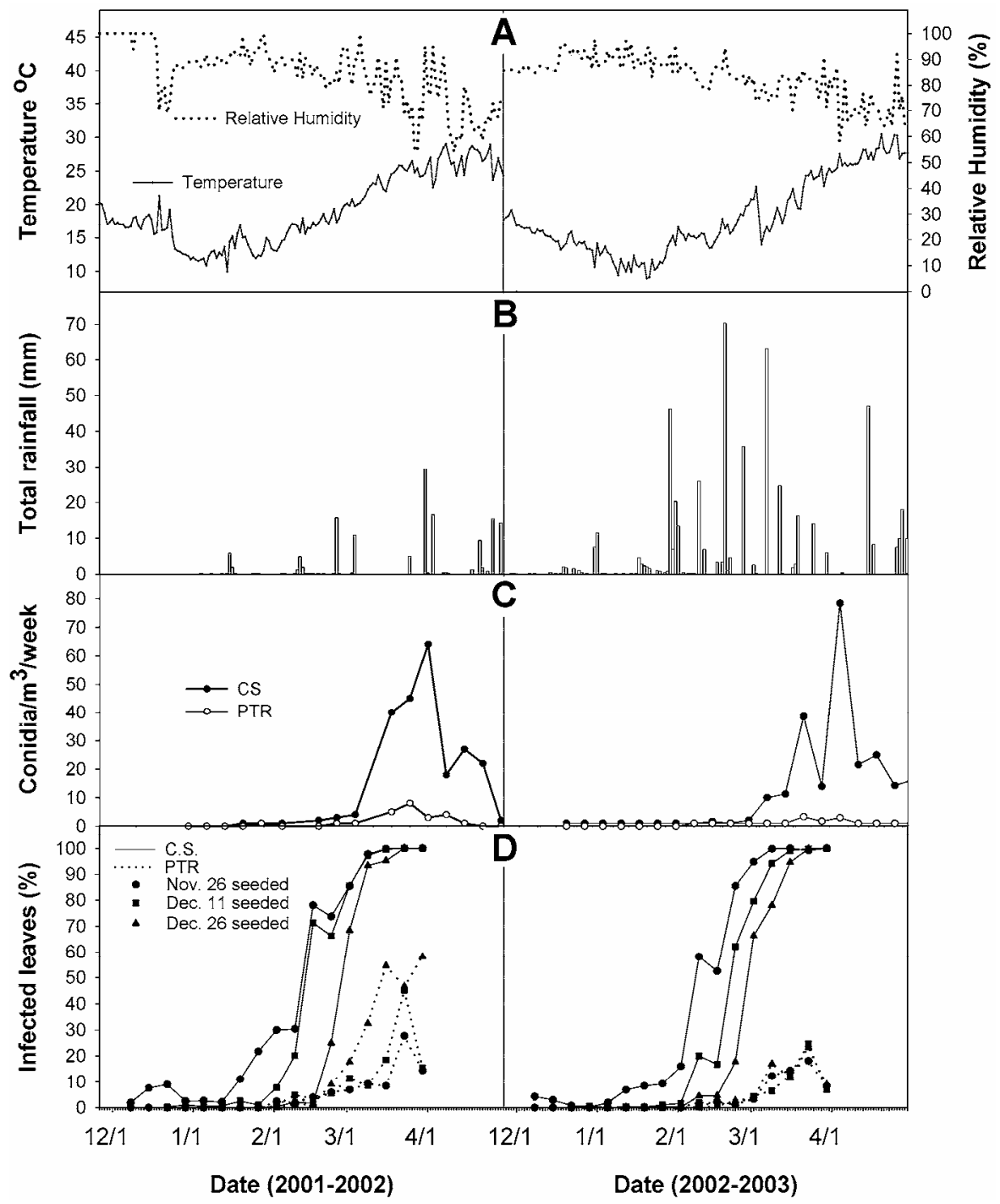

Fig. 1. A, Mean daily air temperature and relative humidity, B, daily rainfall, $\mathbf{C}$, weekly number of conidia in the air $(\mathrm{CS}=$ Cochliobolus sativus; PTR = Pyrenophora tritici-repentis), and D, incidence of leaves infected with the two pathogens recorded during the wheat crop cycle at Rampur, Nepal, in 2002 and 2003. Incidence of infection was determined microscopically after incubation of leaf segments in a moist chamber. 
March (considered critical for foliar blight development across South Asia) was cooler in 2003 than 2002. Mean daily temperature decreased from sowing time until mid-January in both years (Fig. 1A). Relative humidity was higher in 2003 than 2002 during most of the wheat-growing season, with the exception of December. During the study, total rainfall was 143 and $518 \mathrm{~mm}$ in 2002 and 2003, respectively, and the corresponding numbers of rainy days were 16 and 30 (Fig. 1B). For all seeding dates, wheat had reached physiological maturity by 10 April in both years. Although there was higher rainfall in 2003, which contributed to increased relative humidity, the low frequency of rainy days did not hamper disease establishment and development, as shown by the number of leaves of susceptible genotype Sonalika infected by C. sativus by early February in both years (Fig. 2).

Airborne conidia. The first occurrence of $C$. sativus conidia was recorded in the third week of December, whereas $P$. triticirepentis conidia were first detected in the last week of January in both years (Fig. 1C). The air dispersal of conidia of both pathogens remained low through the end of February, when mean temperature was below $20^{\circ} \mathrm{C}$. This was followed by a rise in both temperature and aerial conidial dispersal (Fig. 1A and C). The highest number of conidia of $C$. sativus was observed in the third and fourth weeks of March in 2002 and 2003, respectively, with more than 65 conidia $/ \mathrm{m}^{3} /$ week counted. The number of $C$. sativus conidia in the air was much higher compared with that of P. tritici-repentis.

Pathogen incidence on leaf samples. Infections by $C$. sativus started on lower leaves near ground level within a week after emergence in both years (Fig. 1D). In contrast, leaf infection by $P$. tritici-repentis became evident 6 to 8 weeks after seeding. Despite early detection of $C$. sativus on leaf blades, infection remained at a low incidence for approximately the first 6 weeks for all three planting dates (Fig. 1A and D). However, with $25 \%$ infected leaves observed before the end of January in both years, the overall percentage of infected leaves, regardless of genotype, was considerably higher for the early sowing than the other planting dates (Fig. 2). In the case of P. tritici-repentis, 3 to 4 weeks after the first microscopic observation were needed to reach $25 \%$ infected leaves. Unlike for $C$. sativus, there was no apparent association between $P$. tritici-repentis incidence on leaves and early sowing time.

Overall, there were two to four times more sampled leaves harboring $C$. sativus than $P$. tritici-repentis for all three sowing dates (Fig. 1D). Both pathogens were detected mostly on leaves from a relatively larger number of samples collected from early-maturing, susceptible wheat cultivars (Sonalika, BL 1473, and Nepal 297) than from the three resistant genotypes when temperature was low and the crop was at an earlier growth stage. However, this difference between resistant and susceptible cultivars decreased later in the season (Fig. 2).

Late planting showed reduced seedling infection at an early stage (Fig. 2). However, lower seedling infection had no effect on disease development later in the season, presumably because inoculum developed on early-sown plots was spreading over lateplanted plots. Furthermore, under late-sown conditions, possibly due to increasing temperature, $C$. sativus multiplied quickly as the plants grew and was present on $>90 \%$ of plants of the susceptible genotypes before heading (Zadoks' DC51); whereas, in earlysown plots, it occurred at a later growth stage (Zadoks' DC65). Similarly, there was higher $P$. tritici-repentis incidence in latesown wheat (Fig. 2).

The highest incidence of both pathogens was found during the last week of March (Fig. 1D), when temperature exceeded the threshold level $\left(28^{\circ} \mathrm{C}\right)$ of host resistance breakdown (25). The

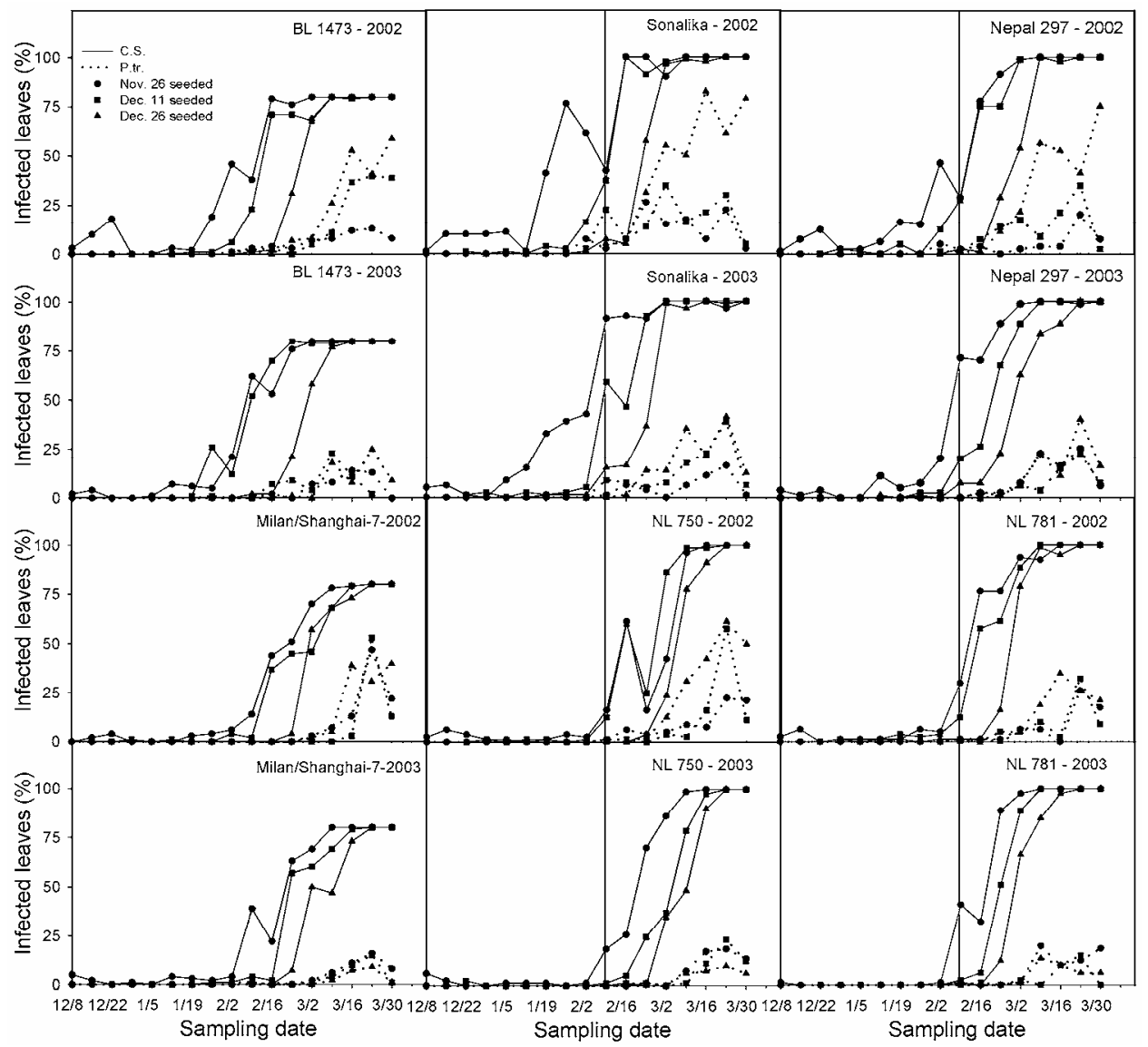

Fig. 2. Influence of genotype and seeding date on the frequency of wheat leaves infected with Cochliobolus sativus (C.S.) and Pyrenophora tritici-repentis (P.tr.) at Rampur, Nepal site in 2002 and 2003. Incidence of infection was determined microscopically after incubation of leaf segments in a moist chamber. 
maximum number of conidia of each pathogen in the air was observed to occur around the same period during the last week of March and first week of April in 2002 and 2003, respectively (Fig. 1C). There was a sharp decline in the number of airborne conidia after the first week of April, corresponding to maturity of the wheat crop in the region.

Foliar blight severity. High HLB severity occurred in both years, as reflected by $>90 \%$ diseased flag leaf area on the highly susceptible cv. Sonalika. No other wheat foliar disease was observed and, in particular, the level of leaf rust (Puccinia triticina) remained negligible during the growing season. Fungicide application fully controlled both pathogens in each year; indeed, there was no incidence of either pathogen on leaves randomly collected from the fungicide-protected plots and then incubated as described above.

Seeding date had a significant effect on AUDPC, AUDPC/day, and AUDPC/DD in both years (Table 1). The AUDPC value was higher for late sowing than early seeding in 2003 but not in 2002 (Table 2), except for cv. Sonalika (Fig. 3). There was even an increase in AUDPC of resistant genotypes under late seeding. In both years, values for AUDPC/day and AUDPC/DD increased as seeding was delayed (Table 2; Fig. 3). Disease severity mean analysis (Table 2) showed that relative ranks across the three seeding dates were different for AUDPC as opposed to adjusted values expressed as AUDPC/day and AUDPC/DD. Mean values for disease severity indicators for the same seeding date also changed in the 2 years, with lower values in 2003 than in 2002.

The effect of maturity group (early and late-maturing genotypes), referred to as "group" in Table 1, as well as its interaction with seeding date, were significant for AUDPC, AUDPC/day, and AUDPC/DD in both years (Table 1). Within the early maturity group, genotypes differed significantly $(P<0.01)$ regardless of the disease variable used, whereas genotypes within the late-maturing group differed only in AUDPC/day and AUDPC/DD $(P<$ $0.05)$ but not in AUDPC. The interaction between genotype and seeding date was always significant only within the early maturing group of genotypes (Table 1). There was lower disease severity, slower disease progress, and higher yield for the late-maturity than the early maturity group (Fig. 3).

The AUDPC value did not show a specific trend across seeding dates, because the highest AUDPC values in 2002 and 2003 were recorded for the 11 and 26 December seeding dates, respectively (Table 2). However, AUDPC/day and AUDPC/DD increased significantly as a function of sowing time from 26 November to 26 December in both years. Analysis of individual genotypes showed a linear trend in AUDPC/day $(0.88<r<0.99,0.02<P<0.07)$ and AUDPC/DD $(0.85<r<0.99,0.02<P<0.13)$ across the three seeding dates in the group of early maturing genotypes in 2003 (Fig. 3). The positive linear relationship of seeding date was nonsignificant in 2002 with both AUDPC/day $(0.13<P<0.24)$

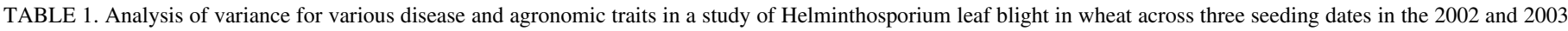
growing seasons in Rampur, Nepal

\begin{tabular}{|c|c|c|c|c|c|c|c|c|c|c|c|}
\hline \multirow[b]{3}{*}{ Source of variation ${ }^{z}$} & \multirow[b]{3}{*}{ df } & \multicolumn{10}{|c|}{ Mean squares ${ }^{\mathrm{y}}$} \\
\hline & & \multicolumn{2}{|c|}{ AUDPC (\%-day) } & \multicolumn{2}{|c|}{ AUDPC/day (\%) } & \multicolumn{2}{|c|}{ AUDPC/DD $\left(\% /{ }^{\circ} \mathrm{C}\right)$} & \multicolumn{2}{|c|}{ Grain yield $\left(\mathrm{t} \mathrm{ha}^{-1}\right)$} & \multicolumn{2}{|c|}{ TKW (g) } \\
\hline & & 2002 & 2003 & 2002 & 2003 & 2002 & 2003 & 2002 & 2003 & 2002 & 2003 \\
\hline Replication & 3 & 20,128 & 5,300 & 71 & 16 & 0.15 & 0.04 & 0.32 & 0.04 & 23.3 & 8.2 \\
\hline Date & 2 & $50,058 *$ & $101,858 * *$ & $3,161 * *$ & $7,603 * *$ & $3.27 * *$ & $10.28 * *$ & $4.78 * *$ & $10.60 * *$ & $582.6 * *$ & $1,148.6 * *$ \\
\hline Error (a) & 6 & 8,843 & 7,719 & 42 & 52 & 0.09 & 0.12 & 0.08 & 0.32 & 7.8 & 4.1 \\
\hline Spray & 1 & $\ldots$ & $\ldots$ & $\ldots$ & $\ldots$ & $\ldots$ & $\ldots$ & $29.99 * *$ & $43.18 * *$ & $2,826.7 * *$ & $2,943.1 * *$ \\
\hline Error (b) & 3 & $\ldots$ & $\ldots$ & $\ldots$ & $\ldots$ & $\ldots$ & $\ldots$ & 0.17 & 0.03 & 17.8 & 7.6 \\
\hline Date $\times$ spray & 2 & $\ldots$ & $\ldots$ & $\ldots$ & $\ldots$ & $\ldots$ & $\ldots$ & 0.36 & 0.20 & $74.5 * *$ & $64.9 * *$ \\
\hline Error (c) & 6 & $\ldots$ & $\ldots$ & $\ldots$ & $\ldots$ & $\ldots$ & $\ldots$ & 0.11 & 0.11 & 3.3 & 2.1 \\
\hline Group & 1 & $9,371,564^{* *} *$ & $7,300,021 * *$ & $55,372 * *$ & $45,930 * *$ & $101.06 * *$ & $92.03 * *$ & $20.27 * *$ & $20.19 * *$ & $641.8 * *$ & $915.1 * *$ \\
\hline Group $\times$ date & 2 & $114,466^{* * *}$ & $20428^{* *}$ & $839 * *$ & $1,536 * *$ & $0.58 * *$ & $2.19 * *$ & $0.33^{*}$ & $1.85^{* *}$ & $39.2 * *$ & $53.5 * *$ \\
\hline Group $\times$ spray & 1 & $\ldots$ & $\ldots$ & $\ldots$ & $\ldots$ & $\ldots$ & $\ldots$ & $0.77 * *$ & 0.46 & $177.8 * *$ & $458.7 * *$ \\
\hline Group $\times$ date $\times$ spray & 2 & $\ldots$ & $\ldots$ & $\ldots$ & $\ldots$ & $\ldots$ & $\ldots$ & 0.16 & 0.30 & $28.1^{* *}$ & $19.9 * *$ \\
\hline Geno/EG & 2 & $504,742 * *$ & $437,653 * *$ & $2,381 * *$ & $1,856^{* *}$ & $4.78 * *$ & $4.21 * *$ & $5.07 * *$ & $1.06^{* *}$ & $672.1 * *$ & $351.5^{* *}$ \\
\hline$(\mathrm{Geno} / \mathrm{EG}) \times$ date & 4 & $63,393 * *$ & $92,050 * *$ & $167 * *$ & $174 * *$ & $0.19 *$ & $0.42 * *$ & $0.63 * *$ & $0.62 * *$ & 2.4 & 2.4 \\
\hline$($ Geno/EG $) \times$ spray & 2 & $\ldots$ & $\ldots$ & $\ldots$ & $\ldots$ & $\ldots$ & $\ldots$ & $0.94 * *$ & $0.96^{* *}$ & $190.5^{* *}$ & $174.4 * *$ \\
\hline$($ Geno/EG $) \times$ date $\times$ spray & 4 & $\ldots$ & $\ldots$ & $\ldots$ & $\ldots$ & $\ldots$ & $\ldots$ & $0.34 * *$ & 0.14 & $16.1 * *$ & 6.8 \\
\hline Geno/LG & 2 & 4,585 & 6,949 & 37 & $79 *$ & 0.09 & $0.15^{*}$ & $2.42 * *$ & $2.90 * *$ & $161.4 * *$ & $185.5^{* *}$ \\
\hline$(\mathrm{Geno} / \mathrm{LG}) \times$ date & 4 & 1,764 & 7,816 & 13 & $92 * *$ & 0.02 & $0.16^{* *}$ & 0.14 & 0.33 & $12.7 *$ & $21.3 * *$ \\
\hline$($ Geno/LG $) \times$ spray & 2 & $\ldots$ & $\ldots$ & $\ldots$ & $\ldots$ & $\ldots$ & $\ldots$ & 0.15 & 0.07 & $23.2^{* * *}$ & $17.0 * *$ \\
\hline$($ Geno $/ L G) \times$ date $\times$ spray & 4 & $\ldots$ & $\ldots$ & $\ldots$ & $\ldots$ & $\ldots$ & $\ldots$ & 0.15 & 0.11 & 2.5 & 0.9 \\
\hline Error (d) & $90(45)$ & 6,961 & 4,157 & 36 & 20 & 0.07 & 0.04 & 0.09 & 0.14 & 3.5 & 3.0 \\
\hline
\end{tabular}

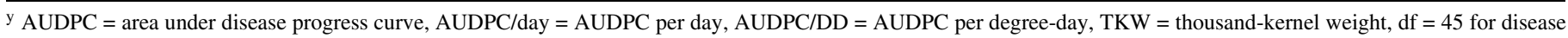
variables and 90 for agronomic traits, $*$ and $* *$ indicate significant at 0.05 and 0.01 probability levels, respectively.

${ }^{\mathrm{z}}$ Date $=$ date of sowing, Group = maturity group, Geno = genotype, EG = early group, LG = late group.

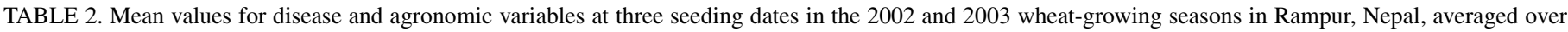
six genotypes ${ }^{\mathrm{z}}$

\begin{tabular}{|c|c|c|c|c|c|c|c|c|c|c|}
\hline \multirow[b]{2}{*}{ Seeding date } & \multicolumn{2}{|c|}{ AUDPC (\%-day) } & \multicolumn{2}{|c|}{ AUDPC/day (\%) } & \multicolumn{2}{|c|}{ AUDPC/DD $\left(\% /{ }^{\circ} \mathrm{C}\right)$} & \multicolumn{2}{|c|}{ Grain yield (t/ha) } & \multicolumn{2}{|c|}{ TKW (g) } \\
\hline & 2002 & 2003 & 2002 & 2003 & 2002 & 2003 & 2002 & 2003 & 2002 & 2003 \\
\hline 26 November & $467 \mathrm{~b}, \mathrm{~A}$ & $356 \mathrm{c}, \mathrm{B}$ & $25 \mathrm{c}, \mathrm{A}$ & $19 \mathrm{c}, \mathrm{B}$ & $1.2 \mathrm{c}, \mathrm{A}$ & $0.9 \mathrm{c}, \mathrm{B}$ & $3.17 \mathrm{a}, \mathrm{A}$ & $3.36 \mathrm{a}, \mathrm{A}$ & $41.5 \mathrm{a}, \mathrm{B}$ & $43.0 \mathrm{a}, \mathrm{A}$ \\
\hline 11 December & $515 \mathrm{a}, \mathrm{A}$ & 397 b, B & $40 \mathrm{~b}, \mathrm{~A}$ & $31 \mathrm{~b}, \mathrm{~B}$ & $1.7 \mathrm{~b}, \mathrm{~A}$ & $1.5 \mathrm{~b}, \mathrm{~A}$ & $2.97 \mathrm{ab}, \mathrm{B}$ & $3.38 \mathrm{a}, \mathrm{A}$ & $37.3 \mathrm{~b}, \mathrm{~B}$ & $38.5 \mathrm{~b}, \mathrm{~A}$ \\
\hline 26 December & $424 \mathrm{c}, \mathrm{B}$ & $484 \mathrm{a}, \mathrm{A}$ & $47 \mathrm{a}, \mathrm{B}$ & $54 \mathrm{a}, \mathrm{A}$ & $1.9 \mathrm{a}, \mathrm{B}$ & $2.4 \mathrm{a}, \mathrm{A}$ & $2.55 \mathrm{~b}, \mathrm{~A}$ & $2.56 \mathrm{~b}, \mathrm{~A}$ & $34.6 \mathrm{c}, \mathrm{A}$ & $33.2 \mathrm{c}, \mathrm{B}$ \\
\hline Mean & $469 \mathrm{~A}$ & $412 \mathrm{~B}$ & $37 \mathrm{~A}$ & $35 \mathrm{~B}$ & $1.6 \mathrm{~A}$ & $1.5 \mathrm{~A}$ & $2.90 \mathrm{~B}$ & $3.10 \mathrm{~A}$ & $37.8 \mathrm{~A}$ & $38.2 \mathrm{~A}$ \\
\hline
\end{tabular}

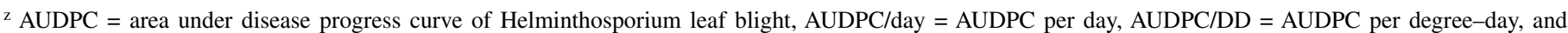
TKW $=$ thousand-kernel weight. Means within a column followed by the same lower-case letter do not differ significantly based on least significant difference at $P=0.05\left(\mathrm{LSD}_{0.05}\right)$, and means for a given trait in a row for the same planting date followed by the same upper-case letter do not differ significantly in the 2 years based on $\mathrm{LSD}_{0.05}$. 
and AUDPC/DD $(0.16<P<0.33)$. The average AUDPC, AUDPC/day, and AUDPC/DD of the late-maturing genotypes were smaller compared with the mean of the three early maturing genotypes (Table 3).

Agronomic traits. The effect of fungicide protection was highly significant $(P<0.01)$ on grain yield and TKW in both years (Table 1). The seeding date-fungicide interaction was significant for TKW but not for grain yield in both years. Matur- ity group effects as well as group-seeding date interactions were significant on grain yield and TKW in both years (Table 1). The three wheat genotypes within each maturity group significantly differed for grain yield and TKW in both years (Table 1).

In both years, mean values for grain yield and TKW were higher for the first two seeding dates than for late seeding on 26 December under both fungicide-protected and nonprotected conditions (Table 2). However, although the lowest values always

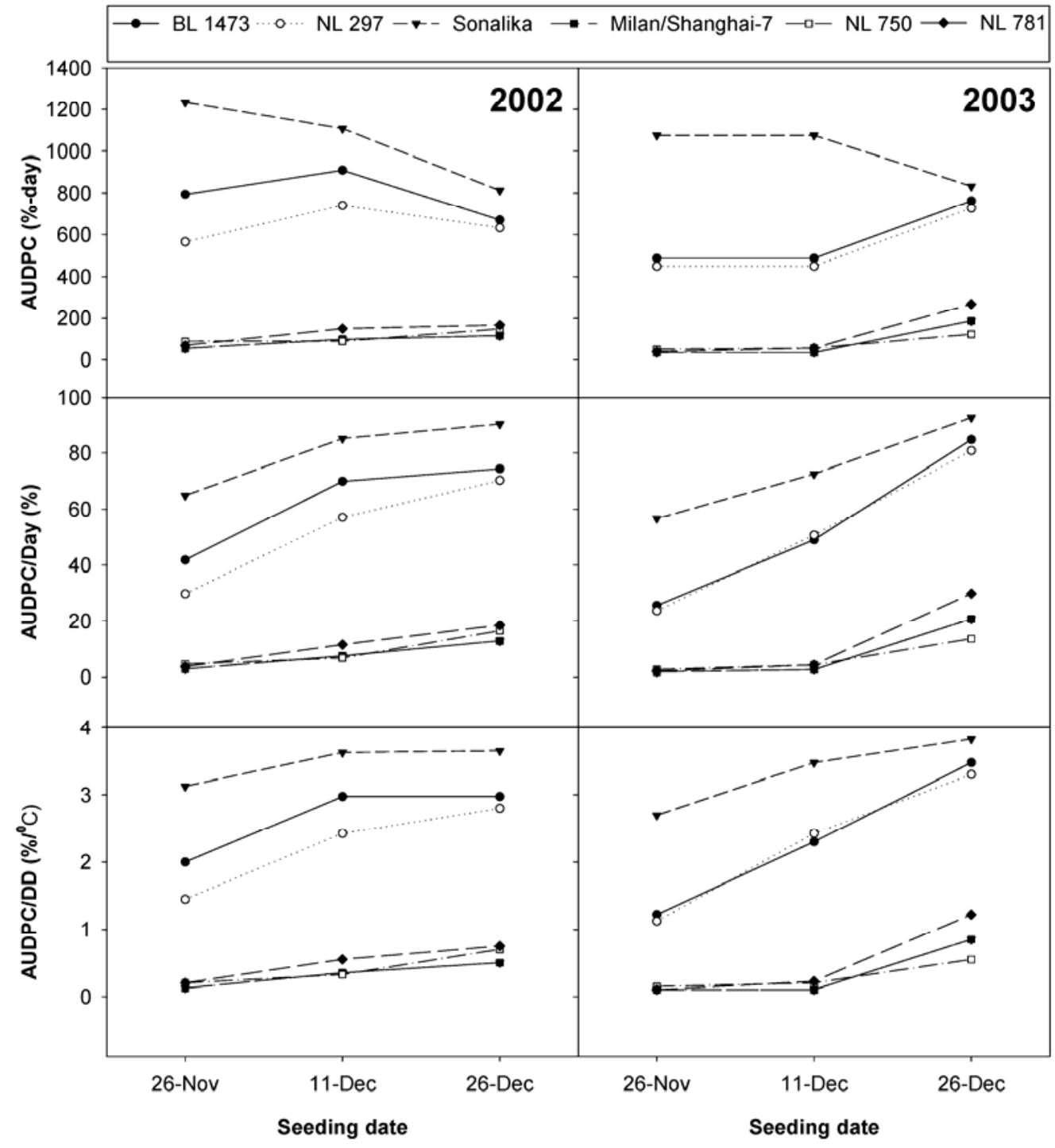

Fig. 3. Change in area under the disease progress curve (AUDPC), AUDPC per day (AUDPC/day), and AUDPC per degree day (AUDPC/DD) of Helminthosporium leaf blight in six wheat genotypes across three seeding dates in the 2002 and 2003 wheat seasons at Rampur, Nepal. BL 1473, Nepal 297, and Sonalika are early maturing whereas Milan/Shanghai-7, NL 750, and NL 781 are late-maturing genotypes.

TABLE 3. Disease variables, grain yield, and thousand-kernel weight (TKW) of six wheat genotypes in a study of the effect of three seeding dates on Helminthosporium leaf blight in the 2002 and 2003 wheat-growing seasons in Rampur, Nepal ${ }^{\mathrm{Y}}$

\begin{tabular}{|c|c|c|c|c|c|c|c|c|c|c|c|c|c|c|c|c|c|c|}
\hline \multirow[b]{2}{*}{ Genotype $^{z}$} & \multicolumn{2}{|c|}{ AUDPC } & \multicolumn{2}{|c|}{ AUDPC/day } & \multicolumn{2}{|c|}{ AUDPC/DD } & \multicolumn{3}{|c|}{ Grain yield in 2002} & \multicolumn{3}{|c|}{ Grain yield in 2003} & \multicolumn{3}{|c|}{ TKW in 2002} & \multicolumn{3}{|c|}{ TKW in 2003} \\
\hline & 2002 & 2003 & 2002 & 2003 & 2002 & 2003 & SP & NSP & Loss & SP & NSP & Loss & SP & NSP & Loss & SP & NSP & Loss \\
\hline P2 & 1,0 & & & & & & & & & & & & & & & & & $\mathrm{a}$ \\
\hline & & & & & & & & & & & & & & & & & & \\
\hline & $89 \mathrm{~d}$ & & 8 & 8 & $3 \mathrm{~d}$ & $0.4 \mathrm{c}$ & 3. & 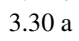 & 1 & $1 \mathrm{a}$ & $\mathrm{a}$ & d & $\mathrm{d}$ & d & & $34.3 \mathrm{~d}$ & $\mathrm{~d}$ & d \\
\hline L 750 & $108 \mathrm{~d}$ & $76 \mathrm{c}$ & $9 \mathrm{~d}$ & $7 \mathrm{c}$ & $0.4 \mathrm{~d}$ & $0.3 \mathrm{c}$ & $3.58 \mathrm{~b}$ & $2.71 \mathrm{~b}$ & $24 \mathrm{c}$ & $3.83 \mathrm{~b}$ & $2.75 \mathrm{~b}$ & $28 \mathrm{c}$ & $41.3 \mathrm{~b}$ & $33.3 \mathrm{c}$ & $20 \mathrm{~b}$ & $40.3 c$ & $34.4 \mathrm{c}$ & $15 \mathrm{c}$ \\
\hline NL 781 & $128 \mathrm{~d}$ & $121 \mathrm{c}$ & $11 \mathrm{~d}$ & $12 \mathrm{c}$ & $0.5 \mathrm{~d}$ & $0.5 \mathrm{c}$ & $3.45 \mathrm{~b}$ & $2.66 \mathrm{~b}$ & $23 c$ & $3.75 \mathrm{~b}$ & $2.75 \mathrm{~b}$ & $27 \mathrm{c}$ & $40.8 \mathrm{c}$ & $33.3 \mathrm{c}$ & $18 \mathrm{~b}$ & $40.8 \mathrm{c}$ & $33.8 \mathrm{c}$ & $17 \mathrm{c}$ \\
\hline
\end{tabular}

${ }^{\mathrm{y}} \mathrm{AUDPC}=$ area under disease progress curve $\left(\%\right.$-day), AUDPC/day $=$ AUDPC per day $(\%)$, AUDPC/DD $=$ AUDPC per degree-day $\left(\% /{ }^{\circ} \mathrm{C}\right)$, grain yield $\left(\mathrm{t}\right.$ ha $\left.{ }^{-1}\right)$ and $\mathrm{TKW}(\mathrm{g})$ for fungicide-sprayed (SP) and nonsprayed (NSP) conditions; loss (\%). Means within a column followed by the same letter do not differ significantly based on least significant difference at $P=0.05$.

${ }^{\mathrm{z}} \mathrm{M} / \mathrm{S}-7=$ Milan/Shanghai -7 
were associated with the 26 December seeding, the differences between the 26 November and 11 December sowing dates were not always statistically significant.

Mean values for grain yield and TKW always were higher in fungicide-protected plots than in nonprotected plots (Table 3). Average grain yield losses due to HLB associated with the 26 November and 11 and 26 December seeding dates were, 20, 30, and $32 \%$, respectively, in 2002 and 18,29 , and $45 \%$, respectively, in 2003 (Fig. 4). Percent yield reductions due to disease differed in the two test years but always were higher for late-sown wheat (Fig. 4). The six genotypes differed for all traits under fungicideprotected and nonprotected conditions, confirming variation in their levels of HLB resistance and agronomic traits (Table 3). Disease variables confirmed genotypic differences among the three susceptible cultivars, with the lowest disease severity observed in BL 1473. Similarly, among the three resistant genotypes, Milan/Shanghai-7 and NL 750 showed lower disease levels than NL 781. Also, Milan/Shanghai-7 presented the highest grain yield but the lowest reductions in grain yield and TKW (Table 3). Among the three susceptible cultivars, BL 1473 showed the lowest reductions for grain yield and TKW. Despite being more susceptible to HLB, BL 1473 showed reductions in grain yield (24\%) and TKW (15\%) comparable to those of resistant genotypes NL 750 and NL 781, suggesting disease tolerance.

\section{DISCUSSION}

Numerous reports have stressed the importance of HLB and, in particular, spot blotch caused by $C$. sativus as major biotic constraint to growing wheat in warmers areas $(6,8,12,14,18,32)$.

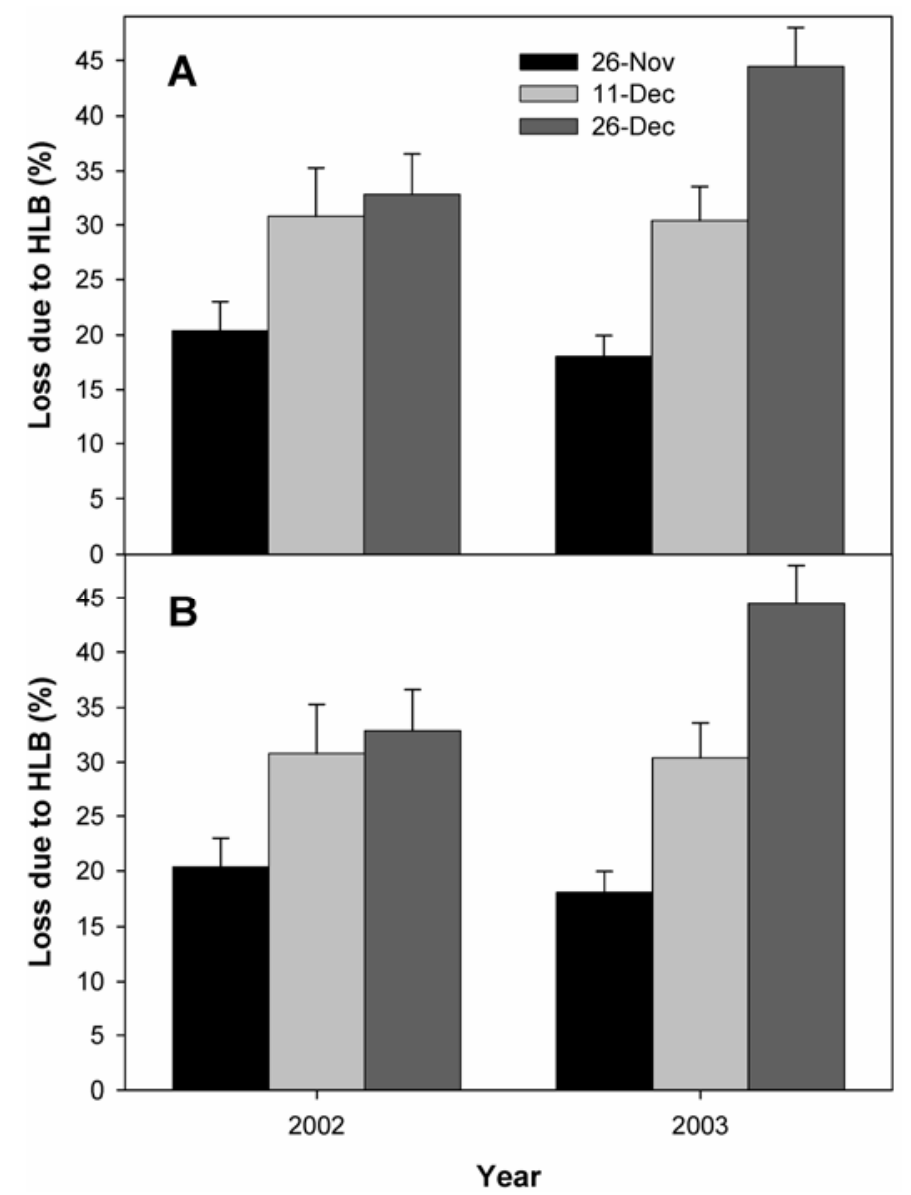

Fig. 4. Losses in A, grain yield and B, thousand-kernel weight due to Helminthosporium leaf blight (HLB) for three seeding dates of wheat in 2 years in Rampur, Nepal. The bars show the standard error for individual means calculated over replications and six genotypes $(n=24)$.
However, this is the first detailed study in the rice-wheat cropping farming system in a warmer climate aimed at understanding the epidemiology of foliar blight in wheat that combines, in the same field experiment, observations on disease progress in wheat genotypes with contrasting levels of resistance, conidia collection in the air above experimental plots, analysis of infected leaf samples, and evaluation of disease effects on grain yield.

Foliar blight development is influenced by high temperature and relative humidity accompanied by long duration of leaf wetness (29). The present study was conducted under winter conditions in South Asia, characterized by the absence of significant rainfall during the first weeks of the wheat-growing season. The relatively low average temperature apparently did not limit the onset of infection by $C$. sativus. Despite the absence of rainfall, the high relative humidity occurring in the Indo-Gangetic Plains as a result of high levels of soil residual moisture at the end of the monsoon and rice crop, along with foggy days that can last until late January, favor long hours of wetness on leaf blades, conditions that are ideal for the establishment and multiplication of wheat pathogens $(7,46)$. Bisen and Channy (3) have shown that conidia of $C$. sativus can germinate completely in $4 \mathrm{~h}$ and infect within $24 \mathrm{~h}$.

Spore collection in 2002 and 2003 showed a clear predominance of $C$. sativus, which is characterized by an abundant multiplication rate, whereas Pyrenophora tritici-repentis is more difficult to observe and, thus, often overlooked $(11,26)$. These results differ from previous, more limited, epidemiological studies in South Asia suggesting that $P$. tritici-repentis dominates early in the wheat season, when the temperature is cool, and that $C$. sati$v u s$ only becomes prevalent when the weather warms up toward the end of the wheat season (10). In Nepal, variable levels of $P$. tritici-repentis incidence have been reported over the years, and C. sativus was considered more prevalent in the early 1990s (10). Sharma et al. (40), however, reported a higher prevalence of $P$. tritici-repentis compared with $C$. sativus across the Nepal lowlands in 3 of 4 years (1998 to 2001), although they did find specific lowland sites where $C$. sativus was predominant. This shows that tan spot is also a potential threat to wheat in the nontraditional, warmer growing areas of South Asia.

The aerial incidence of the two pathogens peaked at approximately the same time. This finding differs from observations by Dubin and Bimb (10) in a lowland location of Nepal, where aerial dispersal of $P$. tritici-repentis conidia peaked in February and C. sativus dominated later in the season, presumably due to the effect of higher average temperature.

Duveiller et al. (15) reported accelerated foliar blight development after flowering (starting from late February until early March) with the advancement of plant growth stage. A significant correlation between age of the plants and leaf susceptibility to HLB was found by Nema and Joshi (25). Tiller and Mehta (42) concluded that older flag leaves were more susceptible to infection by $C$. sativus. Bhatta et al. (2) reported similar results, suggesting a relation between foliar blight development, growth stage, and temperature. In agreement with Ruckstuhl (31), the results of our study indicate that the level of HLB susceptibility changes during the wheat season as a function of plant development. A specific role of growth stage, besides temperature and relative humidity, in the rather low disease development also is suggested by the number of leaf samples infected by $C$. sativus during early growth stages in late-sown plots (after 26 November) compared with timely sown plots on the same observation date, when weather conditions and airborne secondary inoculum were low and similar for plants at all growth stages.

For tan spot, da Luz and Bergstrom (5) reported that, at $28^{\circ} \mathrm{C}$, all wheat plants developed severe foliar blight symptoms regardless of resistant or susceptible genotypes. Similarly, Francl (17) suggested that the inoculum potential of $P$. tritici-repentis was much greater after flowering than before, and that disease in- 
creased with crop maturity. In this study, on a given sampling date, early sown wheat was not necessarily more affected by P. tritici-repentis than late-seeded wheat.

Multiple field disease evaluations instead of a single, final rating have been suggested to properly assess HLB progress in the field and to calculate AUDPC in order to appraise small quantitative changes in disease severity or susceptibility that otherwise would go unnoticed under rapid disease development in warmer wheat-growing areas (13). This method has been used increasingly for detailed germ plasm improvement studies and selection, particularly in Asia $(4,21,40)$. However, based on absolute AUDPC values, it is difficult to determine with precision the extent of HLB damage that may be related to the timely or delayed seeding of wheat and to differences in susceptibility related to early and late maturity. In this study, we included AUDPC/day $(30,36)$ and AUDPC/DD to account for differences in severity resulting from different assessment periods and differences in the number of DDs affecting growth stage and, indirectly, susceptibility. Results indicated that these standardized variables were robust and facilitated detecting differences in severity. AUDPC/day and AUDPC/DD increased significantly as a function of sowing time from 26 November to 26 December in both years. The higher values of AUDPC/day or AUDPC/DD under late-sown conditions likely are caused by heat stress, which enhances HLB development $(25,38)$.

This study confirmed that HLB in South Asia is a disease complex of spot blotch and tan spot, and that combined genetic resistance to both causal pathogens ( $C$. sativus and P. tritici-repentis) is needed in this region of the world. The early maturing genotypes show more disease and greater susceptibility than the latermaturing genotypes, confirming the resistance levels observed by breeders and pathologists. The lower reductions in grain yield and TKW in BL 1473 indicated its tolerance to HLB and confirmed previous observations by Sharma et al (39).

In early growth stages, leaf infection was lower in late, resistant genotypes than in early, susceptible genotypes; however, at more advanced growth stages, differences were smaller. This suggests that higher temperatures and greater inoculum pressure at a later crop growth stage made the plants vulnerable to pathogen attack and led to disease development in resistant genotypes. Because there is no immunity, resistant wheat cultivars, even when seeded very late, would not escape disease damage, especially under high temperatures, which is consistent with the observations of Nema and Joshi (25).

Delayed seeding always showed higher losses for grain yield and TKW, confirming the constraints presented by Hobbs and Giri (19) for wheat grown after rice. However, the present study, which included fungicide treatment, is the first one to clearly show the combined negative effect on wheat yield of foliar blight and heat stress as a result of sowing wheat after the optimum date. This observation confirms the report by Singh et al. (41), who indicated that late-sown wheat fields (December) suffered more from foliar blight than plots sown on the optimum date $(30 \mathrm{No}-$ vember) in eastern India.

The findings of this study have implications for integrated foliar blight management to reduce yield losses under the warm wheat-growing climate of South Asia. By selecting a proper cultivar and adjusting seeding date, effect of high temperatures during grain-filling period that accelerate disease development should be minimized. If planted late, the wheat crop should be treated with a suitable fungicide. Because disease symptoms start in the seedling stage, seed treatment with a suitable fungicide is advisable. BL 1473 and Milan/Shanghai-7 should be preferred among early and late-maturing genotypes, respectively. These two genotypes potentially could be crossed to combine tolerance and resistance to foliar blight along with high yield in the progenies. Maturity of rice and wheat cultivars in the rice-wheat cropping system needs to be combined in a way that would allow wheat grain filling to be completed around mid-March.

\section{ACKNOWLEDGMENTS}

Financial support for this CIMMYT/IAAS collaborative study was made available through Directorate General for Cooperation and Development (Belgium Government) funding to CIMMYT/South Asia. We thank S. Pradhan for assistance in preparing the figures and tables and A. McNab for reviewing the manuscript.

\section{LITERATURE CITED}

1. Aylor, D. E. 1995. Vertical variation of aerial concentration of Venturia inequalis ascospores in an apple orchard. Phytopathology 85:175-181.

2. Bhatta, M. R., Pokharel, D. R., Devkota, R. N., Dubin, H. J., Mudwari, A., Bimb, H. P., Thapa, B. R., Sah, B. P., and Bhandari, D. 1998. Breeding for resistance to Helminthosporium leaf blights in Nepal: Strategies and genetic gains. Pages 188-195 in: Helminthosporium Blights of Wheat: Spot Blotch and Tan Spot. E. Duveiller, H. J. Dubin, J. Reeves, and A. McNab, eds. CIMMYT, Mexico D.F., Mexico.

3. Bisen, P. S., and Channy, B. 1983. Some observations on the surface of wheat leaves during the early stages of infection by Helminthosporium sativum. J. Indian Bot. Soc. 62:285-287.

4. Chaurasia, S., Joshi, A. K., Dhari, R., and Chand, R. 1999. Resistance to foliar blight of wheat: A search. Genet. Resour. Crop Evol. 46:469-475.

5. da Luz, W. C., and Bergstrom, G. C. 1986. Temperature-sensitive development of spot blotch in spring wheat cultivars differing in resistance. Fitopatol. Bras. 11:197-204.

6. da Luz, W. C., and Bergstrom, G. C. 1987. Interactions between Cochliobolus sativus and Pyrenophora tritici-repentis on wheat leaves. Phytopathology 77:1355-1360.

7. de Lespinay, A. 2004. Selection for stable resistance to Helminthosporium leaf blights in non-traditional warm wheat areas. M.S. thesis, Université Catholique de Louvain, Louvain-La-Neuve, Belgium.

8. Dubin, H. J., Arun, B., Begum, S. N., Bhatta, M., Dhari, R., Goel, L. B., Joshi, A. K., Khanna, B. N., Malaker, P. K., Pokhrel, D. R., Rahman, M. M., Saha, N. K., Shaheed, M. A., Sharma, R. C., Singh, A. K., Singh, R. M., Singh, R. V., Vargas, M., and Verma, P. C. 1998. Results of the South Asia regional Helminthosporium leaf blight and yield experiment, 199394. Pages 182-187 in: Helminthosporium Blights of Wheat: Spot Blotch and Tan Spot. E. Duveiller, H. J. Dubin, J. Reeves, and A. McNab, eds. CIMMYT, Mexico D.F., Mexico.

9. Dubin, H. J., and Bimb, H. P. 1991. Effect of soil and foliar treatments on yield and diseases of wheat in lowland of Nepal. Pages 484-485 in: Wheat in Heat-Stressed Environments: Irrigated, Dry Areas and Rice-Wheat Systems. D. A. Saunders, and G. P. Hettel, eds. CIMMYT, Mexico D.F., Mexico.

10. Dubin, H. J., and Bimb, H. P. 1994. Studies of soilborne diseases and foliar blights of wheat at the national wheat research experiment station, Bhairahawa, Nepal. Wheat Special Report No. 36. CIMMYT, Mexico D.F., Mexico.

11. Dubin, H. J., and Duveiller, E. 2000. Helminthosporium leaf blights of wheat: integrated control and prospects for the future. Pages 575-579 in: Proc. Int. Conf. Integrated Plant Dis. Manage. Sustainable Agric. Indian Phytopathological Society, New Delhi, India.

12. Dubin, H. J., and van Ginkel, M. 1991. The status of wheat diseases and disease research in the warm areas. Pages 125-145 in: Wheat in HeatStressed Environments: Irrigated, Dry Areas and Rice-Wheat Systems. D. A. Saunders and G. P. Hettel, eds. CIMMYT, Mexico D.F., Mexico.

13. Duveiller, E. 2004. Controlling foliar blights of wheat in the rice-wheat systems of Asia. Plant Dis. 88:552-556.

14. Duveiller, E., and Gilchrist, L. 1994. Production constraints due to Bipolaris sorokiniana in wheat: Current situation and future prospects. Pages 343-352 in: Wheat in Heat-Stressed Environments: Irrigated, Dry Areas and Rice-Wheat Systems. D. A. Saunders and G. P. Hettel, eds. CIMMYT, Mexico D.F., Mexico.

15. Duveiller, E., Sharma, R. C., Kandel, Y. R., Mercado, D., and Maraite, H. 2003. Genetic resistance and crop management to reduce foliar blight problems in wheat in South Asia. Page 125 in: Abstr. 8th Int. Congr. Plant Pathol. Vol. 2. Christchurch, New Zealand.

16. Eyal, Z., Scharen, A. L., Prescott, J. M., and van Ginkel, M. 1987. The Septoria Diseases of Wheat: Concepts and Methods of Disease Management. CIMMYT, Mexico D.F., Mexico.

17. Francl, L. 1998. Components of the tan spot disease cycle. Pages 28-36 in: Helminthosporium Blights of Wheat: Spot Blotch and Tan Spot. E. Duveiller, H. J. Dubin, J. Reeves, and A. McNab, eds. CIMMYT, Mexico D.F., Mexico.

18. Hetzler, J., Eyal, Z., Mehta, Y. R., Campos, L. A., Fehrmann, H., Kushnir, U., Zekaria Oren, J., and Cohen, L. 1991. Interactions between spot blotch (Cochliobolus sativus) and wheat cultivars. Pages 146-164 in: Wheat for the Nontraditional, Warm Areas. D. A. Saunders, ed. CIMMYT, Mexico D.F., Mexico. 
19. Hobbs, P. R., and Giri, G. S. 1997. Reduced and zero-tillage options for establishment of wheat after rice in South Asia. Pages 455-465 in: Wheat: Prospects for Global Improvement. H.-J. Braun, F. Altay, W. E. Kronstad, S. P. S. Beniwal, and A. McNab, eds. Kluwer Academic Publishers, Dordrecht, The Netherlands.

20. Hosford, R. M., Jr. 1972. Propagules of Pyrenophora trichostoma. Phytopathology 62:627-629.

21. Joshi, A. K., and Chand, R. 2002. Variation and inheritance of leaf angle and its association with spot blotch (Bipolaris sorokiniana) severity in wheat (Triticum aestivum). Euphytica 124:283-291.

22. Maraite, H., Di Zinno, T., Longrée, H., Daumerie, V., and Duveiller, E. 1998. Fungi associated with foliar blight of wheat in warm areas. Pages 293-300 in: Helminthosporium Blights of Wheat: Spot Blotch and Tan Spot. E. Duveiller, H. J. Dubin, J. Reeves, and A. McNab, eds. CIMMYT, Mexico D.F., Mexico.

23. Misra, A. P. 1973. Helminthosporium species occurring on cereals and other Gramineae. U.S.P.L. 480 Project No. A7-CR-133, Grant No. PGIN-223. Tirhut College of Agriculture, Bihar, India.

24. Nagarajan, S., and Kumar, J. 1998. An overview of the increasing importance of research of foliar blights of wheat in India: Germplasm improvement and future challenges towards a sustainable high yielding wheat production. Pages 52-58 in: Helminthosporium Blights of Wheat: Spot Blotch and Tan Spot. E. Duveiller, H. J. Dubin, J. Reeves, and A. McNab, eds. CIMMYT, Mexico D.F., Mexico.

25. Nema, K. G., and Joshi, L. H. 1973. Spot blotch disease of wheat in relation to host age, temperature and moisture. Indian Phytopathol. 26:41-48.

26. Rees, R. G., and Platz, G. J. 1979. The occurrence and control of yellow spot of wheat in north-eastern Australia. Aust. J. Exp. Agric. Anim. Husb. 19:369-372.

27. Rees, R. G., and Platz, G. J. 1992. Tan spot and its control - some Australian experiences. Pages 1-9 in: Advances in Tan Spot Research, Proc. 2nd Int. Tan Spot Workshop. L. J. Francl, J. M. Krupinsky, and M. P. McMullen, eds. North Dakota State University, Fargo.

28. Regmi, A. P., Ladha, J. K., Pasuquin, E. M., Pathak, H., Hobbs, P. R., Shrestha, L. L., Gharti, D. B., and Duveiller, E. 2002. The role of potassium in sustaining yields in a long-term rice-wheat experiment in the Indo-Gangetic plains of Nepal. Biol. Fertil. Soils 36:240-247.

29. Reis, E. M. 1991. Integrated disease management: The changing concept of controlling head blight and spot blotch. Pages 165-177 in: Wheat in Heat-Stressed Environments: Irrigated, Dry Areas and Rice-Wheat Systems. D. A. Saunders and G. P. Hettel, eds. CIMMYT, Mexico D.F., Mexico.

30. Reynolds, K. L., and Neher, D. A. 1997. Statistical comparison of epidemics. Pages 34-37 in: Exercises in Plant Disease Epidemiology. L. J. Francl and D. A. Neher, eds. The American Phytopathological Society, St. Paul, MN.

31. Ruckstuhl, M. 1998. Population structure and epidemiology of Bipolaris sorokiniana in the rice-wheat cropping pattern of Nepal. Pages 88-106 in: Helminthosporium Blights of Wheat: Spot Blotch and Tan Spot. E. Duveiller, H. J. Dubin, J. Reeves, and A. McNab, eds. CIMMYT, Mexico D.F., Mexico.

32. Saari, E. E. 1998. Leaf blight disease and associated soil borne fungal pathogens of wheat in South and Southeast Asia. Pages 37-51 in: Helminthosporium Blights of Wheat: Spot Blotch and Tan Spot. E.
Duveiller, H. J. Dubin, J. Reeves, and A. McNab, eds. CIMMYT, Mexico D.F., Mexico.

33. Saari, E. E., and Prescott, J. M. 1975. A scale for appraising the foliar intensity of wheat disease. Plant Dis. Rep. 59:377-380.

34. Saunders, D. A. 1988. Characterization of tropical wheat environments: Identification of production constraints and progress achieved in South and South East Asia. Pages 12-26 in: Wheat Production Constraints in Tropical Environments. A. R. Klatt, ed. CIMMYT, Mexico D.F., Mexico.

35. Sentelhas, P. C., Pedro, M. J., Jr., and Felicio, J. C. 1993. Effects of different conditions of irrigation and crop density on microclimate and occurrence of spot blotch and powdery mildew. Bragantia 52:45-52.

36. Shaner, G., and Buechley, G. 2002. Field assessment of partial resistance to Puccinia triticina in recombinant inbred lines from wheat cross $\mathrm{CI}$ $13227 \times$ Suwon 92. (Abstr.) Phytopathology 92(suppl.):S75.

37. Shaner, G., and Finney, R. E. 1977. The effect of nitrogen fertilization on the expression of slow-mildewing resistance in Knox wheat. Phytopathology 67:1051-1056.

38. Sharma, R. C., and Duveiller, E. 2003. Effect of stress on Helminthosporium leaf blight in wheat. Pages 140-144 in: Proc. 4th Int. Wheat Tan Spot and Spot Blotch Workshop. J. B. Rasmussen, T. L. Friesen, and S. Ali, eds. North Dakota State University, Fargo.

39. Sharma, R. C., Gyawali, S., Shrestha, S. M., Chaudhary, N. K., and Duveiller, E. 2003. Field resistance to Helminthosporium leaf blight in wheat genotypes from diverse origins. Pages 145-150 in: Proc. 4th Int. Wheat Tan Spot and Spot Blotch Workshop. J. B. Rasmussen, T. L. Friesen, and S. Ali, eds. North Dakota State University, Fargo.

40. Sharma, R. C., Shrestha, S. M., and Duveiller, E. 2003. Incidence of Bipolaris sorokiniana and Pyrenophora tritici-repentis on wheat in the lowlands of Nepal. Pages 122-127 in: Proc. 4th Int. Wheat Tan Spot and Spot Blotch Workshop. J. B. Rasmussen, T. L. Friesen, and S. Ali, eds. North Dakota State University, Fargo.

41. Singh, R. V., Singh, A. K., Ahmad, R., and Singh, S. P. 1998. Influence of agronomic practices on foliar blight, and identification of alternate hosts in rice-wheat cropping system. Pages 346-348 in: Helminthosporium Blights of Wheat: Spot Blotch and Tan Spot. E. Duveiller, H. J. Dubin, J. Reeves, and A. McNab, eds. CIMMYT, Mexico D.F., Mexico.

42. Tiller, C., and Mehta, Y. R. 1997. Effect of wheat flag leaf age in resistance expression to Bipolaris sorokiniana. Summa Phytopathol. 23:167169.

43. Tottman, D. R., and Hilary, B. 1987. The decimal code for growth stages of cereals, with illustrations. Ann. Appl. Biol. 110:441-454.

44. van Ginkel, M., and Rajaram, S. 1998. Breeding for resistance to spot blotch in wheat: Global perspective. Pages 162-169 in: Helminthosporium Blights of Wheat: Spot Blotch and Tan Spot. E. Duveiller, H. J. Dubin, J. Reeves, and A. McNab, eds. CIMMYT, Mexico D.F., Mexico.

45. Watkins, J. E., Odvody, G. N., Boosalis, M. G., and Partridge, J. E. 1978. An epidemic of tan spot of wheat in Nebraska. Plant Dis. Rep. 62:132134.

46. White, J. W., and Rodriguez-Aguilar, A. 2001. An agroclimatological characterization of Indo-Gangetic Plains. Pages 53-65 in: The Rice-Wheat Cropping Systems of South Asia: Trends, Constraints, Productivity and Policy. P. K. Kataki, ed. Food Product Press, New York.

47. Zadoks, J. C., Chang, T. T., and Konzak, C. F. 1974. A decimal code for the growth stages of cereals. Weed Res. 14:415-421. 